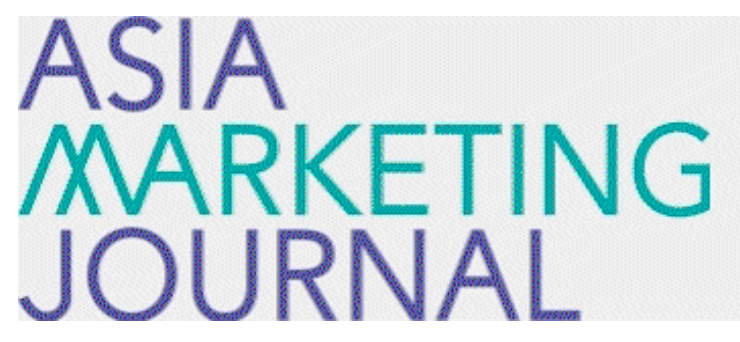

ASIA MARKETING JOURNAL

Volume 16 | Issue 4

Article 6

$1-31-2015$

\title{
A Case Study of Hyundai Motors
}

Myounghwa Choi

Yoonseo Lee

Kay Ryung Koo

Lee

Follow this and additional works at: https://amj.kma.re.kr/journal

Part of the Marketing Commons

\section{Recommended Citation}

Choi, Myounghwa; Lee, Yoonseo; Koo, Kay Ryung; and Lee (2015) "A Case Study of Hyundai Motors," Asia Marketing Journal: Vol. 16 : Iss. 4 , Article 6.

Available at: https://doi.org/10.15830/amj.2015.16.4.75

This Article is brought to you for free and open access by Asia Marketing Journal. It has been accepted for inclusion in Asia Marketing Journal by an authorized editor of Asia Marketing Journal. 


\title{
A Case Study of Hyundai Motors: Live Brilliant Campaign for Modern Premium Brand
}

\author{
Myounghwa Choi* \\ Yoonseo Lee** \\ Kay Ryung Koo*** \\ Janghyuk Lee****
}

\begin{abstract}
As more companies become interested in global markets, it has become crucial for firms to create globalized brands whose positioning, advertising strategy, personality, looks, and feel are consistent across nations. The purpose of this study is to investigate the global branding strategy of the Hyundai Motor Company (hereafter HMC) in order to show how the company processes its branding strategy.
\end{abstract}

HMC, one of the leading global companies in the automobile industry, set up its brand identity as "Modern premium", in alignment with their new slogan "New Thinking New Possibilities", in 2011. The aim of the "Modern premium" concept was to provide consumers with new experiences and values beyond their expectations. HMC wanted their consumers to think of their cars as not only a medium of transportation but as a life space, where they can share experiences alongside HMC.

In an effort to conduct consumer research in 5 different nations, HMC selected "brilliant" as a key communication concept. The word "brilliant" expresses the functional, experiential, and emotional dimensions of HMC. HMC furthermore chose "live brilliant" as a key campaign message in order to reinforce their communication concept. After this decision, the "live brilliant" campaign was exhibited through major broadcast channels around the world. The campaign was the company's first worldwide brand campaign, where a single message was applied to all major markets, with the goal of building up a consistent image as a global brand. This global branding strategy is worth examining due to its significant contribution to growth generation in the global market.

\footnotetext{
* Hyundai Motor Company, Marketing Strategy Group, Vice President

(myoungwha_choi@hotmail.com, myoungwha.choi@hyundai.com)

** Ewha Woman's University, Scranton College, Student(wren.lee@ewhain.net)

*** Korea University, Business School, Ph.D. Student(soma1129@korea.ac.kr)

**** Korea University, Business School, Associate Professor(janglee@korea.ac.kr), Corresponding author
} 
Overall, the 'live brilliant' global brand campaign not only improved HMC's reputation image-wise, with the 'Modern Premium' conceptualization of the brand as 'simple', 'creative' and 'caring', but also improved the consumer's familiarity, preference and purchase intention of HMC. In fact, the "live brilliant" campaign was a successful campaign which increased HMC's brand value. Notably, HMC's brand value increased continuously and reached 9 billion US dollars in 2013, leading it to reach 43rd place in the Global Brand Rankings according to the brand consulting group Interbrand. Its brand value largely surpassed that of Nissan (65th) and Chevrolet (89th) in 2013.

While it is true that the global branding strategy of HMC involved higher risks, it was highly successful according to cross-nation consumer research. Therefore, this paper concludes that the global branding strategy of HMC made a positive impact on its performance. We further suggest HMC to combine its successful marketing with social media such as Facebook, Twitter, and Instagram and embrace digital media by extending its brand communication horizon to the mobile internet

Key words: Hyundai motor company, Global branding strategy, Brand identity

\section{Introduction}

Hyundai Motor Company (hereafter HMC), one of leading global companies in the automobile industry, launched the 'live brilliant' campaign in order to position its brand as a modern premium brand that provides emotional value and experience by exceeding its customers' expectation. The goal of this communication campaign was to refresh HMC's brand perception and image by reinforcing its brand identity.

Brand identity is the consumer's perception of the brand as is intended by the firm. Keller (1993) defined brand identity as brand components such as the brand's name, communication style, logo and other visual elements which would identify the firm's goods and services to differentiate them from those of competitors. A strong brand identity enhances brand value as well as consumer's satisfaction (He et al., 2012; Chun and Davies, 2006), and it is the up to the brand manager to build up a strong brand identity.

Developing an appropriate brand identity is an especially important and challenging decision for HMC. The brand manager for a global company can choose to either build a brand identity that is consistent across all target markets or to develop country-specific branding strategies. An advantage to creating a globally consistent branding strategy is that it is more efficient to manage across the markets due to economies of scale, however when there are strong cultural differences the global branding strategy cannot be imposed on all markets (Aaker 
et al., 1999). Therefore, it is important for HMC to determine whether its global brand identity is sufficiently well-defined and performing efficiently across nations.

The goal of our research is to analyze HMC's brand communication campaign and its performance in order to demonstrate the effectiveness of HMC's brand management strategy. In order to accomplish this goal, we start by addressing the development process of the HMC's brand identity concept along with its company profile. Next, we will focus on the case of "Live Brilliant" campaign and its performance across nations. Unlike HMC's previous campaigns, the "Live Brilliant" campaign was the company's first worldwide brand campaign where a single message was applied to all major markets, with the goal of building up a consistent image as a global brand (HMC news, 2012). The breakdown of this study is as follows 1) company profile, 2) the development process of the brand communication concept, 3) a case of Live Brilliant campaign, 4) campaign performance, and 5) future challenges of $\mathrm{HMC}$.

\section{Company Profile}

HMC was established in 1967 and launched its own designed car 'Pony' in 1976. It opened Hyundai Motor Canada in 1983 and Hyundai
Motor America in 1985. It started to export its compact car 'Excel' to U.S. in 1986 and recorded 1 million units of 'Excel' production in 1989. In 1994, HMC surpassed annual production of 1 million units. Its quality driven strategy fruited as its 'Sonata' received the best performance, driving, and design surveyed by J.D. Power in 2002. In 2003, HMC recorded the annual export of 1 million units. HMC received numerous awards such as Elantra '2012 North American Car of the Year' at the Detroit Auto Show, TAU engine the winner of US Ward's AutoWorld 201010 Best Engines for the third consecutive year, Genesis Car of the Year in North America (2009), i30 Car of the Year in Australia (2007).

HMC operates seven factories overseas (US, China, India, Czech Republic, Turkey, Russia, and Brazil) producing 86\% of total production. In 1997, its first overseas factory was inaugurated in Istanbul, Turkey and its latest one in Sao Paulo, Brazil in 2012.

\section{Development Process of Brand Communication Concept}

HMC launched its new brand direction at the 2011 North American international Auto Show in January, announcing its new brand direction of 'Modern Premium'. 'Modern premium' is based on the concept that today's car buyers 
〈Figure 1〉 Sales Evolution

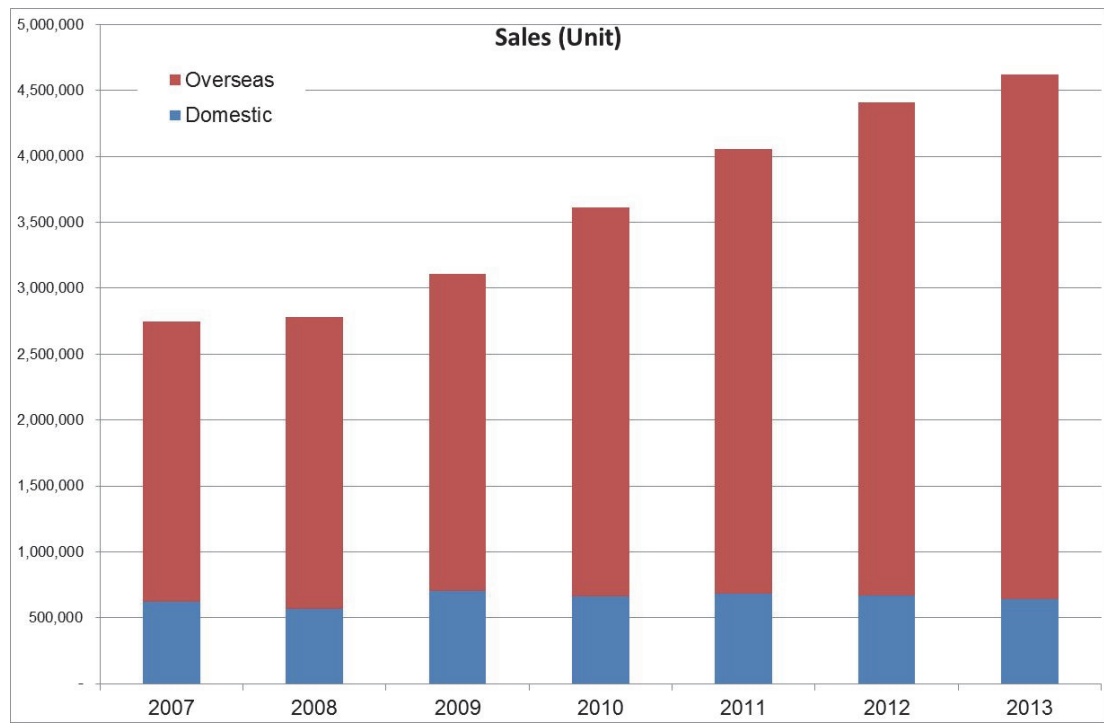

(source: HMC annual report)

want more from a car than just status and extra features for features' sake. HMC wanted a car that is not only used as a means of transportation, but as a 'Life Space' (HMC news, 2012). As 'Modern Premium' was set as HMC's brand identity to be shared by its employees and stake holders, it was crucial for its strategy marketing group to find an appropriate expression to be shared by its customers.
Restructuring brand communication was necessary for harvesting the fruit of its quality improvement efforts such as implementing the 10 year 100,000 mile warranty to change its old fashioned brand image by producing affordable good cars. Since the introduction of the revolutionary warranty program its price gap vis-à-vis direct competitors among top tier manufacturers such as Toyota gradually decreased. Table 1 shows

$\langle$ Table 1〉 Sonata vs. Camry

\begin{tabular}{rrrcccc}
\hline & \multicolumn{3}{c}{ Base price } & \multicolumn{3}{c}{ Feature-adjusted total price } \\
Year & Sonata & Camry & Gap & Sonata & Camry & Gap \\
\hline 2008 & 22,470 & 25,000 & $(2530)$ & 24,270 & 27,433 & $(3163)$ \\
2009 & 24,550 & 25,575 & $(1025)$ & 26,675 & 29,932 & $(3257)$ \\
2010 & 24,550 & 25,952 & $(1402)$ & 27,075 & 28,949 & $(1874)$ \\
2011 & 25,495 & 26,725 & $(1230)$ & 28,590 & 29,280 & $(690)$ \\
2012 & 26,445 & 24,775 & 1670 & 29,540 & 29,505 & 35 \\
\hline
\end{tabular}

(source: www.truedelta.com) 
the price of Hyundai Sonata (model 'Limited') and that of Toyota Camry (model 'XLE'). Hyundai Sonata's base price approached that of the Toyota Camry with a difference of less than \$1500 in 2010 and its feature-adjusted total price was closing the gap even faster. Therefore HMC inevitably needed a new brand communication strategy to effectively deliver the changed image of its brand. In 2012 Sonata's base price and feature-adjusted total price finally overpassed that of Camry.

In order to develop the brand communication concept, consumer research was conducted on a global scale. Research was undertaken in five major markets, including India, South Africa, Chile, China, Russia, and Turkey, in order to analyze the life style of target consumers, market trends as well as the needs, attitudes, and expectations of 'Modern Premium'. This market research result brought the communication concept 'brilliant', which laconically expresses the brand identity of 'Modern Premium' in order to make customers more easily understand the concept and to convey the key benefits of HMC cars.

In 2005, HMC set its brand identity as 'Refined and Confident' and conducted a series of global brand campaign with a 'Drive Your Way' in 2008. This campaign expressed HMC's confidence to become a key player of the global automobile industry. The campaign 'Drive Your Way' was appropriate to express an dynamic and powerful image of HMC, but it was not able to deliver the sophisticated and upscale brand image that $\mathrm{HMC}$ wanted to attain in order to keep up with the fast-paced marketplace. Two years into a global brand communication project, HMC came up with the new brand slogan 'New Thinking New Possibilities' and conducted its 'live brilliant' campaign in order to establish its brand identity of 'Modern Premium'.

Through the use of 'brilliant', HMC was able to conjure up splendid and remarkable images and emotions. The fact that the word 'brilliant' can also be used to encompass and express functional, experiential, and emotional dimensions

〈Figure 2〉 Campaign Slogan 'live brilliant' Development Process

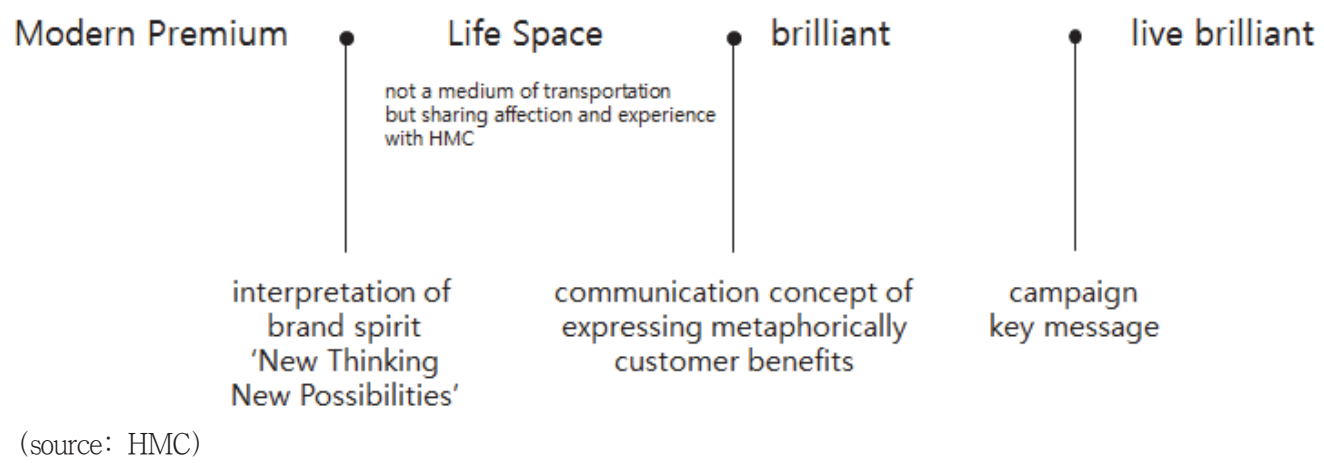

A Case Study of Hyundai Motors: Live Brilliant Campaign for Modern Premium Brand 79 
〈Figure 3〉 Brand Communication Concept 'brilliant' Structure

$\begin{array}{ll} & \text { self actualization } \\ \text { \& self esteem } & \text { object for emotional interaction }\end{array}$

Passionate Contemporaries (target customer analysis)

emotion \& culture

quality of life

my own style and value

high level achievement \& professionalism new \& diverse experience

brilliant

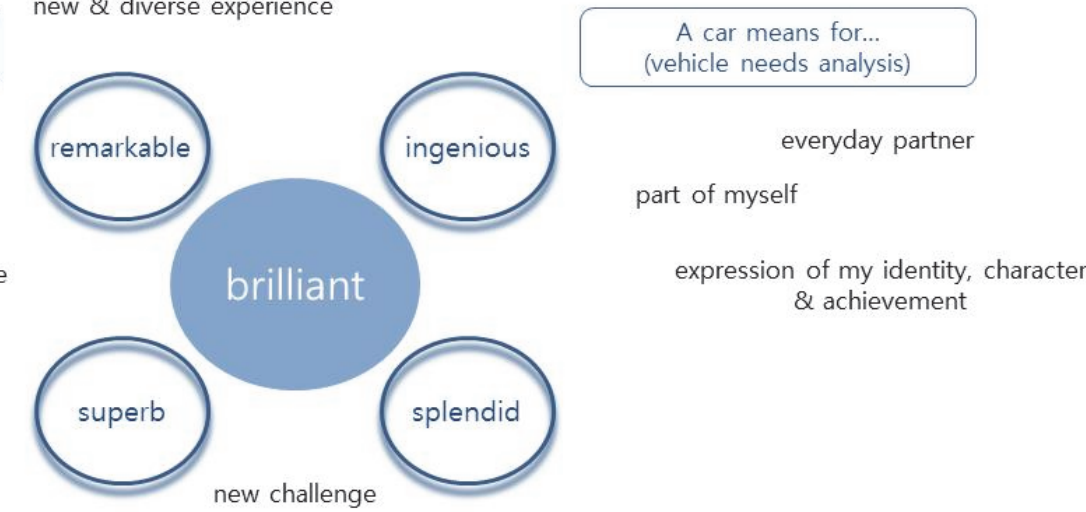

friend sharing my code

young \& fresh

contemporary premium

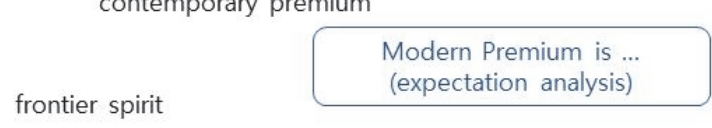

innovative, forward looking

creating my own value and expression

simple but luxurious \& unique style

premium of principles

(source: HMC)

image-wise in a versatile manner was also brand value. HMC entered Interbrand's top 100 highly appreciated. brand value ranking in 2005. Since its entry,

HMC's marketing performance was compenits brand value has been increasing continuously sated not only by its sales but also by its and $\mathrm{HMC}$ reached $43^{\text {rd }}$ place in 2013 with a

〈Figure 4〉 The Meaning of 'brilliant'

$\begin{array}{llll}\text { Function } & \text { Experience } & \text { Image } & \text { Emotion } \\ & \text { Remarkable } & \text { Splendid } & \text { Superb } \\ \text { Ingenious } & \text { More than excellent } & \text { Bright } & \text { Amazing } \\ \text { Smart } & \text { Extraordinary } & \text { Shiny } & \text { Outstanding } \\ \text { Intelligent } & \text { Experienced } & \text { Radiant } & \\ \text { Clever } & & & \\ \text { Sophisticated } & & & \\ \text { (source: } \mathrm{HMC} \text { ) } & & & \end{array}$


〈Figure 5〉 HMC's Brand Value Evolution

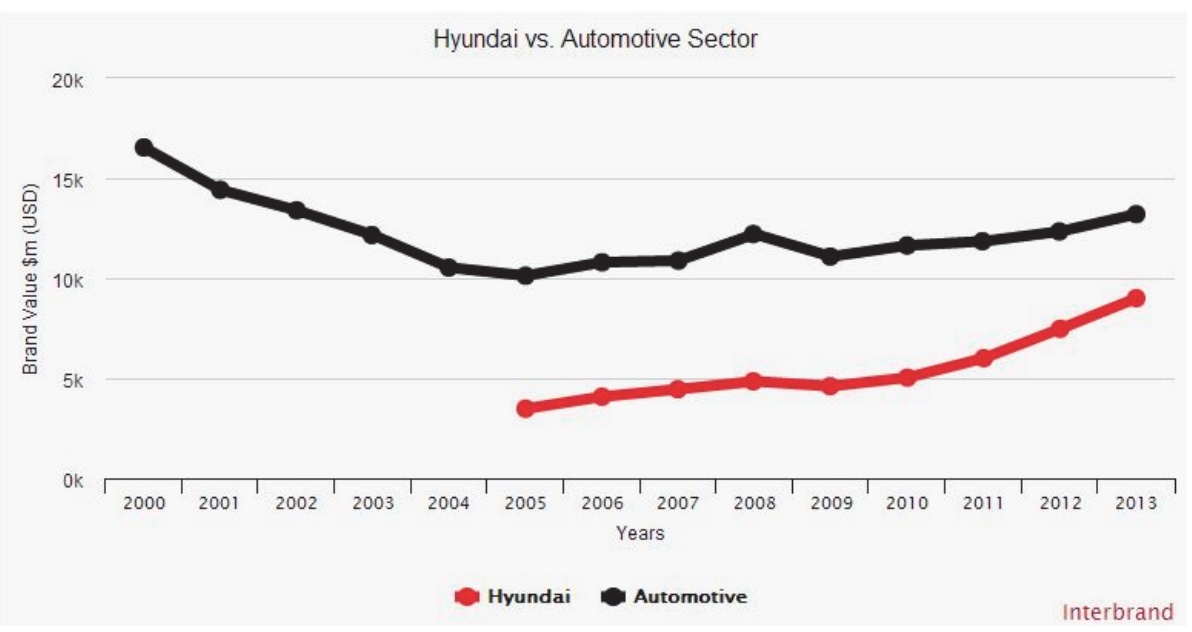

(source: Interbrand)

value of 9 billion US dollars. Its brand value largely surpassed of Nissan (65th) and Chevrolet (89th) in 2013.

\section{Case of Live Brilliant Campaign}

The 'live brilliant' campaign slogan was derived from the brand communication concept of 'brilliant' by the advertising agency Innocean. Starting from 2012, HMC has launched a global brand campaign under the slogan "live brilliant' which focuses on the narratives of the consumer's life space. The ad series aims to communicate 'brilliance' while creating a rapport with the audience by placing themselves on the same standing as the target audience and conveying sincerity through story telling with emotional touch. The intention of the message of 'live brilliant' was to communicate the image of a more brilliant and unique everyday lifestyle with Hyundai and captivate the consumer to boost the brand's familiarity and preference.

\subsection{Campaign activities}

On January 10th 2011, vice-chairman Eui-Sun Chung unveiled HMC's new brand identity 'Modern Premium' as well as their new slogan "New Thinking New Possibilities" at the North American international motor show. Vice-chairman Chung stated that "In order to satisfy the customer's desires in an era of fast-paced changes, it is necessary to provide an emotional satisfaction which surpasses their expectations." The declared brand identity of "Modern Premium" 
was derived from the idea that Hyundai Motors ("hyundai' meaning modern in Korean) was at the foremost of modernity and then defining this exclusive quality as a premium. The vicechairman then proceeded to say that "Hyundai Motors would build upon new ideas about customers and cars in order to find and provide value in new ways" and revealed that "this brand identity can be described by our new slogan: New Thinking New Possibilities."

Following the conference, numerous communication efforts were expended both domestically and internationally in order to promote the brand's new identity and slogan. On February 1st 2011, in an effort to promote the slogan in an impactful manner, 427 Sonatas were harnessed to film the mega orgel advertisement series, which were the first to include the new slogan. These ads were launched in Korea then promoted worldwide in 25 different countries. In the ad series, we can see countless Sonatas racing together before synchronizing to form the slogan 'New Thinking New Possibilities' in a dynamic manner. However, the ads received positive feedback from consumers as they were considered 'bold' and 'innovative'. The audio of the ads featured sounds made by the formation as they traveled through a $87 \mathrm{~m}$ deep tunnel-like structure, similarly to an orgel. While filming a series of ads on automobiles inspired by the orgel, an instrument mostly associated with children's toys and jewel boxes, is unusual, the scale of the advertisements is also notable. The series featured the most vehicles out of all Hyundai advertisements up to then, and countless stunt drivers and test drives were necessary in order to maintain formation at the high speed of $120 \mathrm{~km} / \mathrm{h}$. Two helicopters were also used in order to capture the dynamic footage. The tune created when the $\mathrm{H}$ part of the formation passed through the 'orgel' in the ad was used as the HMC sound

\section{〈Figure 6〉 Grand Orgel TV Commercial}

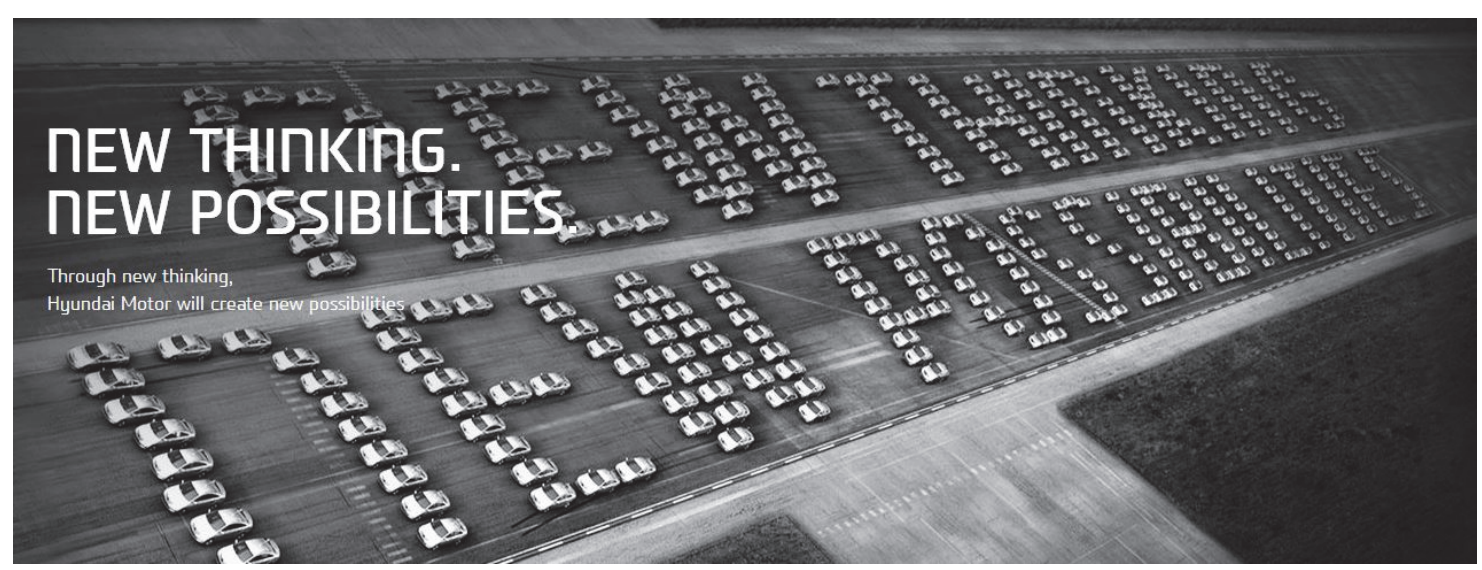

(source: brand.hyundai.com) 
signature at the end of all ads, further re- $^{-}$ inforcing the bold intent behind their slogan.

In conjunction to the ads, HMC also showed active participation in social media, as can be seen through the "8 New Thinkers" digital campaign, launched in February 2011. In this campaign 8 social leaders, Sang-Bong Lee (fashion designer), Oi-Soo Lee (novelist), Byung-Man Kim (comedian), Myung-Bo Hong (soccer player), Hong-Bin Kim (alpinist), Yoon-Ju Jang (model), Tae-Jong Im (reverend), and Yuna Kim (figure skater), who were considered self-made leaders at the top of their field, were recruited to communicate with consumers about the power of new ideas, which allowed HMC to subtly promote their new brand slogan "New Thinking New Possibilities".

On April 2011, HMC collaborated with YouTube to sponsor the "YouTube Symphony Orchestra", a digital campaign which featured the novel idea of creating an orchestra concert entirely out of YouTube-uploaded video auditions and ended in success. Later that year, in November, the company collaborated with MSN to create the "New Thinkers Index" campaign in order to create diverse, new content inspired by the "New Thinking New Possibilities" slogan.

In late 2011, a new campaign was devised to showcase the slogan's message in an innovative and original manner. An interactive electronic racing game was hosted on the billboard of Times Square, at the center of New York. Players could control the Veloster on billboard through use of their iPhones by installing the Hyundai racing app and connecting to the wifi. The campaign was highly successful and acclaimed as engaging and innovative.

\subsection{Live brilliant campaign}

The two advertising series 'Laughter' and 'Style' clearly and effectively delivered the message and image related to the main theme of 'special feelings in a daily life' by focusing on emotional ('Laughter') and sensual ('Style') aspects.

The two campaigns were broadcast through major TV programs around the world. In 2011 HMC had slightly different position across countries. Among seven key foreign markets, it

〈Table 2〉 Campaign Description

\begin{tabular}{|l|l|l|}
\hline \multicolumn{1}{|c|}{ Campaign } & \multicolumn{1}{|c|}{ Laughter } & \multicolumn{1}{c|}{ Style } \\
\hline Key value & Familiar \& kids \& laugh & Luxurious \& sophisticated \& splendid \\
\hline Focus & Emotional aspect (familiar, comfortable ad) & $\begin{array}{l}\text { Sensual aspect (visually splendid and } \\
\text { refined ad) }\end{array}$ \\
\hline $\begin{array}{l}\text { Reinforced image } \\
\text { after watch }\end{array}$ & $\begin{array}{l}\text { - Caring customer/society/environment } \\
- \text { Understanding customer, taking care of } \\
\text { emotion }\end{array}$ & $\begin{array}{l}\text { - Perfection, simplicity } \\
\text { - Luxurious, taking responsibility }\end{array}$ \\
\hline
\end{tabular}


〈Figure 7〉 'Laughter' TV Commercial Screen Shots

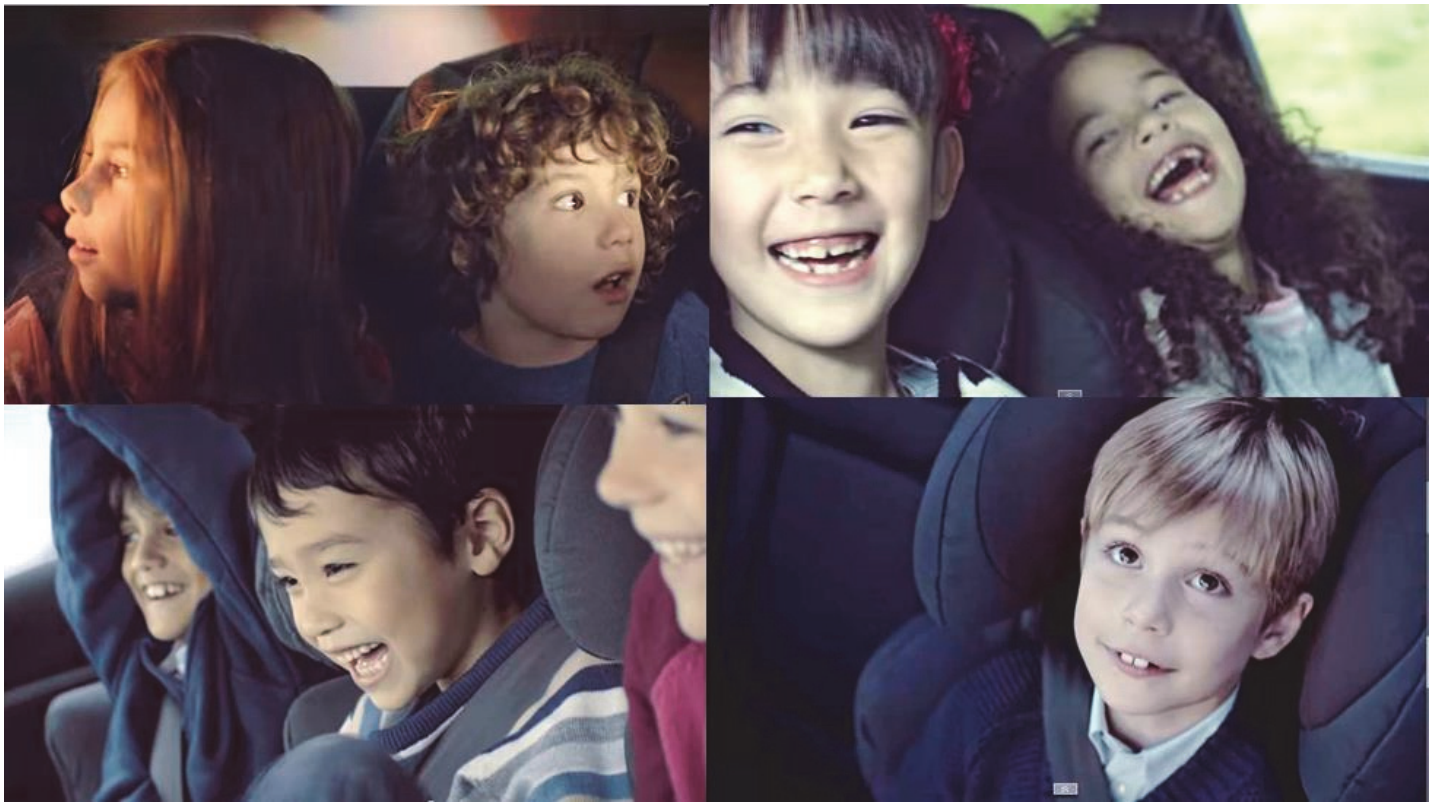

(source: YouTube 'HyundaiWorldWide')

〈Figure 8〉 Style TV Commercial Screen Shots

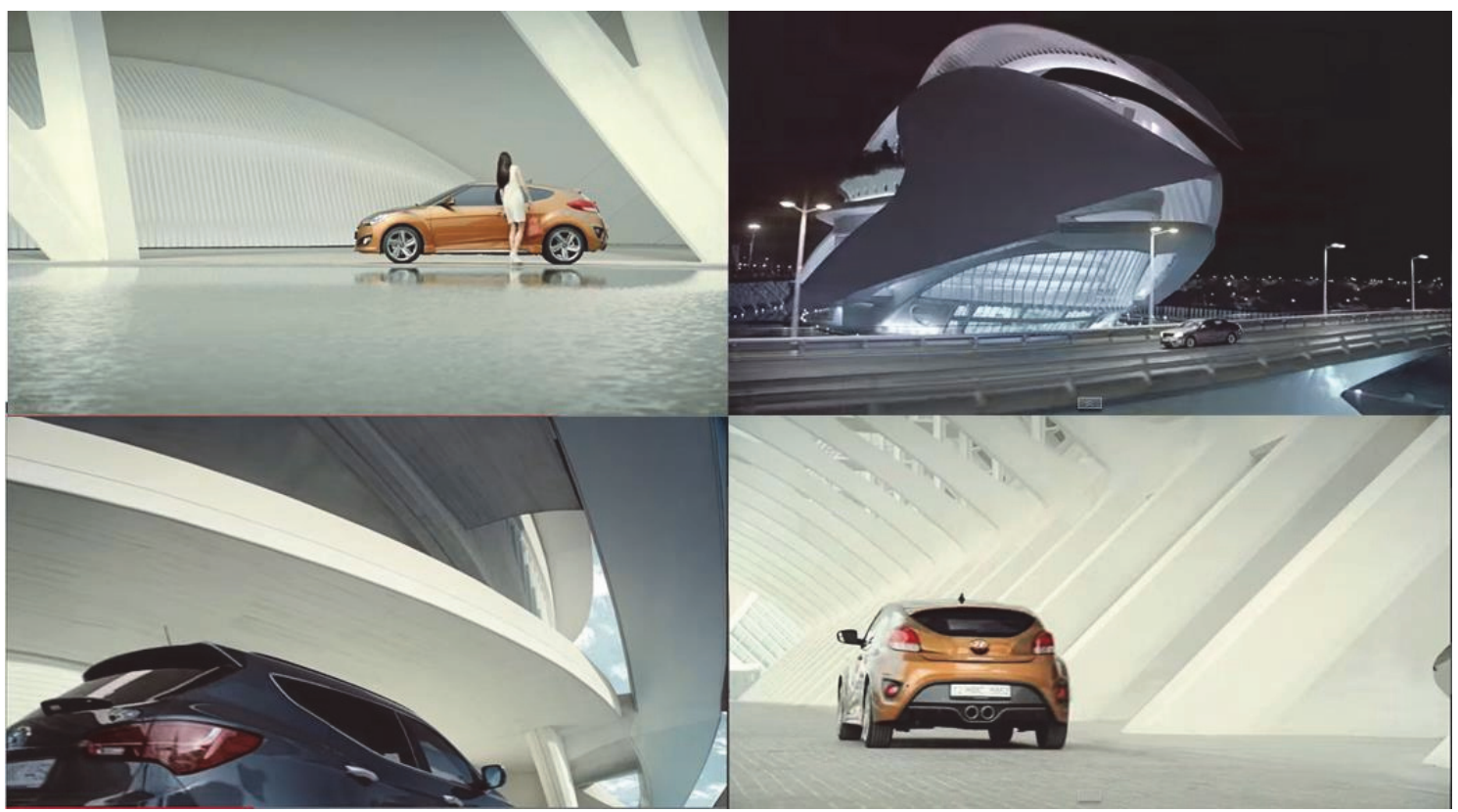

(source: YouTube 'HyundaiWorldWide')

84 ASIA MARKETING JOURNAL Vol. 16 No. 04 January 2015 
recorded a two digit market share in India, Chile, and Saudi Arabia where unaided brand awareness level was higher than in the single digit market share countries. To compensate for relatively low brand awareness HMC made efforts to raise exposure to TV advertising in China and South Africa, measured as gross rating points (GRP). These campaigns were not conducted in Russia and there was a technical error when measuring GRP in Turkey. (presented as not available)

\subsection{Campaign Performance}

Campaign performance was assessed by measuring the gap between respondents who were aware of advertising and those who were unaware of advertising. For each respondent, brand image related questions were asked and their response was measured on a 7 point scale.

Overall the 'live brilliant' global brand campaign improved the brand's 'Modern Premium' related images such as 'simple', 'creative' and 'caring' by $7.0 \%, 9.3 \%$, and $11.5 \%$. Furthermore, brand funnel related indexes were improved. (familiarity by $7.4 \%$, preference $6.7 \%$, consideration $7.3 \%$, and purchase intention 8.6\%) Respondents expressed positive appreciation towards the campaign advertising, with its stylish and luxurious touch as well as familial values being of particular note. Across countries, Chile showed the highest campaign perform-

〈Table 3〉 Market Information \& Ad Exposure

\begin{tabular}{|l|r|r|r|r|r|r|r|}
\hline & \multicolumn{1}{|c|}{ India } & South Africa & \multicolumn{1}{c}{ Chile } & \multicolumn{1}{c}{ China } & Russia & \multicolumn{1}{c|}{ Turkey } & Saudi Arabia \\
\hline Market share & $14.9 \%$ & $6.8 \%$ & $10.5 \%$ & $5.7 \%$ & $5.9 \%$ & $6.0 \%$ & $16.1 \%$ \\
\hline Unaided brand awareness & $82.4 \%$ & $52.6 \%$ & $68.5 \%$ & $51.3 \%$ & $46.4 \%$ & $53.5 \%$ & $76.0 \%$ \\
\hline GRP & 1116 & 2803 & 2449 & 5243 & - & N.A. & 3848 \\
\hline
\end{tabular}

(source: HMC)

〈Table 4〉 Campaign Results

\begin{tabular}{|c|c|c|c|c|c|c|c|c|c|}
\hline & & India & South Africa & Chile & China & Russia & Turkey & Saudi Arabia & Average \\
\hline \multirow{4}{*}{ Creative } & Creative & 6.0 & 13.4 & 18.6 & 13.8 & 7.5 & 14.5 & 3.9 & 11.1 \\
\hline & Original & 8.1 & 19.5 & 15.0 & 12.4 & 3.8 & 21.0 & 3.3 & 11.9 \\
\hline & Smart & 3.2 & 11.4 & 16.1 & 13.5 & 0.9 & 14.3 & 7.6 & 9.6 \\
\hline & Progressive & 9.7 & 10.2 & 20.7 & 9.3 & 1.1 & 19.0 & 7.2 & 11.0 \\
\hline \multirow{4}{*}{ Caring } & Caring & 10.3 & 18.1 & 22.7 & 14.4 & 2.6 & 14.2 & 11.8 & 11.8 \\
\hline & Responsible & 16.7 & 21.5 & 28.9 & 14.5 & 0.5 & 18.7 & 14.0 & 16.4 \\
\hline & Sustainable & 10.8 & 16.6 & 32.4 & 13.0 & 9.8 & 19.3 & 11.8 & 16.2 \\
\hline & Sensible & 10.1 & 24.9 & 27.4 & 16.7 & 5.3 & 20.7 & 7.3 & 16.1 \\
\hline \multirow{4}{*}{ Simple } & Simple & 5.9 & 13.4 & 22.6 & 7.3 & 0.6 & 9.2 & 5.4 & 9.2 \\
\hline & Intuitive & 2.7 & 10.0 & 11.4 & 6.0 & - & 11.9 & - & 6.0 \\
\hline & Impeccable & 8.8 & 16.9 & 14.8 & 14.0 & 6.6 & 17.5 & 4.3 & 11.8 \\
\hline & Proud & 9.7 & 14.7 & 12.1 & 12.3 & 4.6 & 18.8 & 2.8 & 10.7 \\
\hline \multirow{2}{*}{ Modern premium } & Global & 6.1 & 1.9 & 3.4 & 7.3 & - & 12.6 & - & 4.5 \\
\hline & Premium & 8.4 & 14.6 & 16.4 & 19.5 & 17.2 & 15.2 & 3.3 & 13.5 \\
\hline Average & & 8.3 & 14.8 & 18.8 & 12.4 & 4.3 & 16.2 & 5.9 & 11.4 \\
\hline
\end{tabular}

(source: HMC) 
ance (18.8 point improvement on average). The campaign result in Saudi Arabia was disappointing, showing low performance despite heavy TV ad exposure (GRP of 3848 which means 3.8 exposures on average), however it is interesting that a positive campaign result was recorded in Russia (4.3 point improvement on average) even though no TV advertisements were programed.

\section{Future Challenges}

HMC has to capture solid consumer base influenced by its new brand identity of 'Modern Premium' across countries. To create a new brand identity at global level HMC conducted 'Live brilliant campaign' with the same contents around the world. It resulted not only in brand image change but also in price gap closing vis-à-vis competing brands. In order to foster its new brand identity of 'Modern Premium' HMC needs to embrace digital media by extending its brand communication horizon to the mobile internet. Previously, HMC relied mainly on traditional advertising platforms, such as television, for its brand communication which failed to be cost efficient. HMC opened its YouTube channel in 2011 and started to invest in digital media substantially starting from 2013, after having been stimulated by the success of its sister company, Kia Motors. Kia
Motors took the initiative of intensifying its marketing activities on digital platforms, in conjunction with traditional advertising platforms, and has recorded six 10 million pageview videos as of September 2014. Since its expansion to digital platforms, HMC has recorded two 10 million pageview videos (FIFA World Cup and the empty convoy). Therefore, there are high expectations for the success of HMC's future integrated digital marketing activities combining other social media such as Facebook, Twitter, and Instagram.

〈Received October 7. 2014〉 〈Accepted December 10. 2014〉

\section{References}

Aaker, D. A. and E. Joachimsthaler (1999), "The lure of global branding," Havard Business Review, November-December, 137144.

Chun, R. and G. Davies (2006), "The influence of corporate character on customers and employees: exploring similarities and differences," Journal of Academy of marketing science, 34(2), 138-46.

He, H., Y. Li and L. Harris (2011), "Social identity perspective on brand loyalty," Journal of Business research, 65, 648-657.

HMC annual reports, http://pr.hyundai.com/ \#/Pages/Intro/Report/ReportList.aspx 
Interbrand 'Global Top 100 Brands' http:// www.interbrand.com/en/best-global-brand s/2013/Hyundai

Keller, K. L. (1993), "Conceptualizing, Measuring, and Managing Customer-Based Brand Equity," Journal of Marketing, 57(1), 1-22.

YouTube sources

Campaign 'Laughter' commercial http://www.youtube.com/watch?v $=$ tbF8 ttNv3hw\&index $=14 \&$ list $=$ PL264BC8962 CC27533
Campaign 'Mega orgel' commercial http://www.youtube.com/watch? $\mathrm{v}=\mathrm{s} 6 \mathrm{v}$ JvVxnEVM

Campaign 'Style' commercial http://www.youtube.com/watch?v = xw8 dyevjc $-\mathrm{w} \&$ list $=$ PL264BC8962CC27533\&in $\operatorname{dex}=13$

Hyundai race in Time Square http://www.youtube.com/watch? $\mathrm{v}=\mathrm{Oa}$ TXvHhiEIo

YouTube orchestra 2011 http://www.youtube.com/watch?v = MT fYGqfFSXE 